\title{
Racialised body modifications: framing genital mutilation, cosmetic surgery and gender assignment surgery
}

\author{
DR. MATHIS DANELZIK, Institute for Advanced Studies in the Humanities
}

\begin{abstract}
This article investigates the racial framing of genital modifications in political and media contexts. It suggests that a racialised understanding of genital mutilation, cosmetic surgery on the vulva and the vagina, as well as gender assignment surgery on intersexual minors, predetermines policy decisions regarding the practices. In the first part of the analysis, I discuss some of the major inconsistencies that emerge from the categorisation of these practices. The second part of the article addresses media representations of genital modifications. It asks how the incomparability of what is framed as mutilation and what is framed as cosmetic surgery is upheld. Based on the British television show Embarrassing Bodies and an episode of the German series Tatort, the article shows how the rationality and autonomy of practitioners of genital modifications are construed differently depending on their racial framing.
\end{abstract}

\section{KEYWORDS}

Framing; Race; Othering; Identity; Female Genital Mutilation; Intersexuality

\section{On not making the connections: Framing genital mutilation as an African problem incomparable to Western practices}

Female genital mutilation, cosmetic surgery on vagina and vulva, gender assignment surgery on intersexual minors, sex change operations, amputation of the male foreskin, genital piercings and severe modifications of the genitals as sexual fetishes: all of these practices have their own complex contexts, motives and variants. Yet, they are all irreversible modifications of the human genitals. This article analyses how media portrayals of, and political reactions to, modifications of human genitals depend on racialised framings. Those frames determine whose practices are problematic and those which constitute rational expressions of autonomy. I discuss the resulting inconsistencies, which are prime examples of how racialised frames still permeate the media and international politics. This critique against political and media discourse on body modifications should not be misconstrued as belittlement of the harms of what is commonly understood as female genital mutilation in Africa. During my research on campaigns against this practice in Tanzania, I met many women who have suffered from these practices and I have written about the challenges to end them extensively elsewhere (Danelzik forthcoming).

This analysis consists of two sections. In the first part, I intend to demonstrate how a racial framing of female genital mutilation, cosmetic surgery on the vulva and vagina and gender assignment surgeries on intersexual minors dictates contradictory policies towards the practices, to the detriment of various groups. In the second part, I am specifically concerned 
with how media representations uphold the incomparability between what is framed as genital mutilation and what is framed as cosmetic surgery. This is done through an analysis of Embarrassing Bodies, a television show promoting cosmetic surgery, and an episode of the German crime series Tatort that deals with African female genital mutilation.

There are more nuanced analyses on racialised notions of body modifications available such as, for example, Carolyn Pedwell's (2012) contribution. She argues that even finespun feminist writing on body modifications that avoids deeming Western and non-Western practices incomparable, still relies on racialised framings. Here, I focus on the deep inconsistencies that exist in the mainstream understanding of these issues and, therefore, this article does not deal with the different cultural contexts of various practices to the desirable extent. Given the far-reaching political and material consequences of the inconsistent framing of various body modifications, I contend that a critique of them, be it flawed itself, is of paramount importance.

\section{Genital modifications and the politics of postcolonialism}

In the 1970s, Western feminists brought female genital mutilation in Africa to the limelight for the second time, after the practice had received a first wave of Western attention during European colonial occupation of Africa. In 1982, American anthropologist Ellen Gruenbaum criticised the work of the two best known feminist, anti-genital mutilation activists at the time: Fran Hosken and Mary Daly. Daly (1981) understood female genital mutilation as a sadistic act, men being the perpetrators, women being brainwashed, 'mentally castrated' victims. Gruenbaum (1982) argued that this description not only failed to explain why the practice was widespread and stable in twenty-eight African countries, but it also depicted African practitioners as being sick, brutal and primitive, hampering any useful efforts to end the practice (6). Thus, Gruenbaum was one of the first Western authors to acknowledge the postcolonial critique of the international genital mutilation discourse, notably during a conference of the United Nations World Women's decade from 1975 to 1985 in Copenhagen (Gosselin 2000, 44).

Since then, the postcolonial critique has maintained that Western representations of the practice have never been freed from a neo-colonial understanding. However, the most criticised works by Western feminists stem from the 1990s. Since then, international political discourses have reacted to the postcolonial critique in various ways. Today, development agencies and non-governmental organisations ascribe to conducting culturally sensitive and participatory campaigns to end the practice. This begs the question of whether the postcolonial critique, which is regularly renewed (Nnaemeka 2005), is still relevant. Is the understanding of the issues still racially charged?

\section{Tolerance for mutilations framed as cosmetic surgery}

The United Nations (UN) distinguish various forms of female genital mutilation, as shown in the following table. Three aspects of this classification are striking. First, it shows the serious nature of most of the practices commonly understood as female genital mutilation. Secondly, some Western practices, such as partial removal of the clitoral hood and partial removal of the labia minora, which are framed in the West as cosmetic surgery on vagina and vulva, ${ }^{1}$ are

\footnotetext{
${ }^{1}$ Cosmetic surgery on the female genital can affect the vagina (vaginal rejuvenation) or the vulva (for example, removal of the labia minora). For simplicity, I will henceforth speak of cosmetic surgery on the vulva. However, vaginal rejuvenation is an important practice that also falls under the definition of mutilation given by the UN.
} 
specifically mentioned as mutilations in this classification. Finally, the definition of female genital mutilation is so broad ('all injury to the female genital organs for non-medical reasons') that actually all existing and conceivable cosmetic surgery on the female genital is defined as mutilation. Motives, risks, circumstances, maturity, informed consent, autonomy, play no role whatsoever. This is a position of zero tolerance on vulva modification. In contrast, a liberal definition would give precedence to the criteria of maturity, autonomy and informed consent (Mackie n.d.).

\begin{tabular}{|l|l|l|l|}
\hline Type & Term & Subtype & Definition \\
\hline I & $\begin{array}{l}\text { Clitori- } \\
\text { dectomy }\end{array}$ & Ia & Removal of the clitoral hood or prepuce only \\
\hline & & Ib & Removal of the clitoris with the prepuce \\
\hline II & Excision & IIa & Removal of the labia minora only \\
\hline & & IIb & Partial or total removal of the clitoris and the labia minora \\
\hline & & IIc & $\begin{array}{l}\text { Partial or total removal of the clitoris, the labia minora } \\
\text { and the labia majora }\end{array}$ \\
\hline III & Infibulation & IIIa & Removal and apposition of the labia minora \\
\hline & & IIIb & Removal and apposition of the labia majora \\
\hline IV & Other & & $\begin{array}{l}\text { All procedures involving partial or total removal of the } \\
\text { external female genitalia or other injury to the female } \\
\text { genital organs for non-medical reasons }\end{array}$ \\
\hline
\end{tabular}

(UNFPA and UNICEF 2008, 24)

However, even though all cases of cosmetic surgery on the vulva fall under the definition of female genital mutilation, modifications which are framed as cosmetic surgery are not understood and treated as such. This unequal treatment is so frequent that the UN agencies mention it in their document on female genital mutilation, although they not follow it through. They write: 'some practices, such as genital cosmetic surgery and hymen repair, which are legally accepted in many countries and not generally considered to constitute female genital mutilation, actually fall under the definition used here'. Nevertheless, they continue: 'it has been considered important, however, to maintain a broad definition of female genital mutilation in order to avoid loopholes that might allow the practice to continue' (UNFPA and UNICEF 2008, 24).

It is remarkable that the agencies make the connection between their non-liberal stance on vulva modification and cosmetic surgery on the vulva, but they disregard this observation and seem to apologise to the assumed reader stating that they needed to find a broad definition, even though it includes Western practices. This passage exemplifies the current double standard of the United Nations agencies: they do not concern themselves with what they frame as cosmetic surgery, even though it constitutes genital mutilation according to their own definition. ${ }^{2}$

\footnotetext{
${ }^{2}$ In fact, this definition is so broad that it would also include gender assignment surgery on adult consenting intersexual human beings, as well as sex change operations on adult consenting transsexual human beings, unless it is determined that the psychological harm resulting from no modification is predominant, which it might not be in all cases. It would also make foreskin amputation of male consenting adults questionable. Given the proposed logic, men would not be able to consent to a foreskin amputation, unless it is deemed medically based. Apart from being a treatment to phimosis, this question is complicated in that there are certain medical advantages to being circumcised (Gray et al. 2007). The issue, in this case, is whether these would be sufficient to consider an amputation to be medically based. There is an ongoing debate about whether parents have the
} 
This double standard not only exists internationally, but also nationally. Sheldon and Wilkinson (1998) discuss this in Great Britain (269-270), Nikki Sullivan (2007) in Australia, and Essén and Johnsdotter (2004), who find this double standard to be in breach of the democratic tenet that all citizens are to be treated equally before the law, focus on the Scandinavian countries (611-613). Yet, there is more evidence to suggest that the response to modifications of the vulva not only depends on which practices are executed, but also on who executes them.

\section{Zero-tolerance against minimally invasive practices framed as genital mutilation}

This double standard also extends to practices which are less invasive than genital piercings. However, as long as they are framed as mutilation, they are prohibited and campaigned against. Unfortunately, even minimally invasive practices are regularly framed as such. Among other cases, these practices have been requested in Somalia (Shell-Duncan and Hernlund 2000, 5), and in Italian (Galeotti 2007, 91) as well as American hospitals (Coleman 1998). The proposed procedure involves doctors who, under hygienic conditions in the controlled environment of the hospital, sting the girl's clitoris or their prepuce with a sterile needle in order to produce a drop of blood. Reformed practices have, in some cases, been developed in collaboration with practicing communities in order to satisfy cultural requirements.

In 2010, the American Academy of Paediatrics (AAP) proposed to offer this practice, although organisations involved in ending female genital mutilation consistently oppose the idea. In this instance, the organisation Equality Now led the actions, claiming in an open letter that even this kind of minimally invasive procedure constitutes female genital mutilation (FGM in their abbreviation) and is a human rights violation which must be 'eradicated'. They make the following comparisons:

Some other harmful traditional practices include early marriage, which occurs in many countries in which FGM is practiced, and, historically, foot binding in China. In comparison, the AAP's recommendations to "nick" a girl's clitoris would be the equivalent of suggesting marriage at 12 years old, instead of 8 , or binding the girl's toes, instead of her entire foot. A reduction in the severity of a human rights violation does not supplant the gravity of such a violation (Equality Now 2010).

Equality Now does not establish what kind of harm this minimally invasive procedure causes. Therefore, their comparison with binding toes and allowing twelve-year-old children to marry does not stand. The UN agencies WHO, UNFPA, UNICEF and UNIFEM (2010) concur with the position of Equality Now and emphasise in their response that all forms of female genital mutilation are wrong, failing to address the fundamental inconsistencies of their position. They do not clarify in what ways this minimally invasive practice violates human rights, or why the practice of male foreskin amputation does not, or why far more invasive procedures executed under the label of 'cosmetic surgery' do not violate human rights either.

right to order the amputation of the foreskin of their minor children, or whether the child's right to bodily integrity reigns supreme (Benatar and Benatar 2003; Rennie, Muula and Westreich 2007; Schultheiss 2010; UNAIDS 2010). However, there isn't a serious contention regarding the removal of the foreskin of adult consenting men. Nevertheless, if the proposed logic were looked through, it would be called into question. 
While many - including the author - might deem such a practice senseless and unnecessary, the proposed practice of pricking would leave no scarring, it would not impede sexual function or pose considerable medical risk. The practice is less invasive than genital piercings, which can be obtained from non-medical professionals in Germany and many other Western societies by minors with consent of their guardians (Kasten 2006, 348). To be clear, in the vast majority of cases of 'African' female genital mutilation, guardians decree highly invasive, irreversible and dangerous practices on minors who are unable to consent. This often happens in social environments with enormous social pressures on the guardians as well as on the children. Nevertheless, most organisations and contributors to the discourse treat as self-evident that a minimally invasive practice, such as pricking, should be understood as genital mutilation even if performed by doctors - if the people involved are of African descent. ${ }^{3}$ Issues of informed consent, maturity, and absence of overwhelming social pressure - i.e. liberal criteria - do not even enter the discussion as long as it is framed as being about 'African' female genital mutilation. Neither do comparisons to other practices falling under the UN zero-tolerance definition of genital mutilation.

\section{Cultural vs. medical: overlooking similarities between female genital mutilation and gender assignment surgery on intersexual minors}

The practice of female genital mutilation is the best known example of what is called 'harmful traditional practices' by the UN (UNHCR 1995). The term 'traditional' implies that the practices in question are culturally embedded and seem to be legitimate options or even social norms. Note that the term is not 'harmful cultural practices', but 'traditional' practices. This suggests that the practices are seen as desirable because they are a tradition. Indeed, arguments of tradition, as well as traditionalism as an ideology, serve to legitimise female genital mutilation, son preference, child marriage and many other practices which are usually understood as harmful traditional practices. This does not justify, however, prioritising this angle of justification over the dozens of other ways in which these practices may also become justified, including perceived medical benefits as well as aesthetic and gender ideals. The relevance of these arguments is an empirical question which cannot be assumed in definitions, since stressing the role of tradition can be analytically misleading when trying to understand or end the practices. Furthermore, underscoring tradition in the definition of harmful cultural practices serves another function: it directs the attention away from Western practices and onto non-Western practices. The Western world perceives itself as the epitome of modernity, which equals rationality and sees itself as opposite to the cultural and, even more so, to the traditional:

While being modern seemed to be the hallmark of Western societies, all the societies of the so-called Third World were categorized as traditional. [...] In principle, however, the opposition between modernity and tradition was nothing else but a kind of self-definition of neo-colonial Western culture that provided it with a feeling of

\footnotetext{
${ }^{3}$ However, there is sometimes reasonable ground to treat cases differently. The risks of allowing reformed practices in countries where female genital mutilation is a social norm and where hospital staff might be more inclined to perform invasive procedures under the disguise of minimally invasive practices have to be considered. Advantages and disadvantages of the nicking option under these circumstances need to be discussed further (Shell-Duncan 2001). Drawing on my research in Tanzania, it seems clear that practitioners would try to exploit the fine line between permitted and prohibited body modifications in order to continue with their preferred invasive practices. However, the conditions of such proposals are very different in European and American contexts, where hospital personnel generally abhor what they frame as African female genital mutilation and where special precautions could be implemented.
} 
superiority and, at the same time, legitimated the ongoing oppression and exploitation of the rest of the world (Kohl 2006, 97).

This self-image leads to overlooking the similarities between practices of one's own society and those of Others (Jeffreys 2005). The framing of gender assignment surgery on intersexual minors needs to be placed within this context. Indeed, African proponents of female genital mutilation and Western proponents of gender assignment surgery on intersexual minors share remarkably similar arguments: the reasons for both practices are cultural, but not medically justifiable (although some cases and syndromes of intersexuality are medical emergencies, I exclude these from this comparison). Most of the time, surgeons who perform gender assignment on minors do not provide treatment which is medically necessary, but they enforce gender norms (Ehrenreich and Barr 2005, 104).

Gender assignment usually attempts to achieve penetrable vaginas and penises that are able to penetrate a vagina (Reiter 1999, 96). From this perspective, a clitoris which is considered too long or a penis which is considered too short pose questions about the dichotomy between male and female (Fausto-Sterling 2000, 59). Therefore, they are moulded into a clitoris or penis of 'appropriate' appearance. If it is decided to shape the genital into an 'appropriate' clitoris, this is achieved by cutting a part in the middle and reconnecting the severed head of the clitoris with its body, or, a more frequent practice nowadays, by folding it under some skin in a way that the protruding part fits the surgeons' gender and aesthetic ideal of a clitoris (Green 2005, 165-166). While the UN definition of genital mutilation applies here, the practices are not considered as such by the UN organisations.

Gender assignment surgery is complex and can have life-long consequences and serious physiological and psychological complications:

If a vagina has been constructed for a child, the entrance to the vagina must be manually dilated with vaginal inserts every day to prevent the opening from closing. [...] While studies of the psychological effects of intersex treatments are shockingly few, testimonials from intersex treatment recipients repeatedly mention the sense of shame, humiliation, and violation that physical examinations and surgical treatments engender. In addition, many patients experience these surgeries and examinations as acts of violence, frequently analogizing them to rape and sexual abuse (Ehrenreich and Barr 2005, 107-108).

Gender assignment surgery may disturb sexual experience and can make it impossible for gender assigned persons to self-determine the anatomy of their genitals later in their life (Ehrenreich and Barr 2005, 110). Both female genital mutilation and gender assignment surgery are based on the belief that humans can be born unnatural (Pedwell 2007, 53). In both practices, a key argument is the risk of stigmatisation if children are left 'undone' (Sullivan 2007, 402; Kessler 1998, 35), so both practices are usually decided upon by parents for their children (Boulware-Miller 1985; Shell-Duncan 2008, 231).

For decades, doctors have turned ambivalent genitalia into a medical problem as if this and its surgical treatment were self-evident. Gender assignment surgery has benefitted from the authority that doctors have given to the arbitrary definition of a 'hypertrophied clitoris' and the goal to achieve 'natural' genitalia through surgical intervention (Ehrenreich and Barr 2005, 118). Ehrenreich and Barr conclude: 
In labelling female circumcision as a harmful cultural practice that should be eliminated while simultaneously failing to criticize intersex cutting, mainstream anti$\mathrm{FGC}^{4}$ discourse constructs the former as inaccurate and "unscientific" and the latter as a rational response to objective medical truths $(2005,86)$.

\section{The relevance of the postcolonial in the critique of body modification discourses}

Given that very severe forms of body modifications affect women and people with ambivalent genitalia, a full analysis of body modifications would need to intersect critically issues of race, patriarchy and heteronormativity (also regarding the amputation of the male foreskin). Focusing here on the racialisation of body modification, it is clear that the understanding of body modifications is still mainly racialised, with far-reaching negative consequences for different groups and populations. First, human beings born with genitalia that do not fit cultural norms are subjected to life-altering surgery without being able to consent to it. This is the case in most of the practices which are usually framed as African female genital mutilation and as gender assignment surgery.

Secondly, minimally invasive procedures which are culturally motivated are fought against if they are sought by Africans, even if they do not carry considerable harm. While women's rights to self-determination and health are violated in most cases of what is framed as African female genital mutilation, the right to self-determination of African women is also violated when minimally invasive procedures are forbidden and African women's autonomy to decide is not considered in these deliberations. Thirdly, Western societies permit genital modifications on Western women, even though they should be seen as violating their human rights under the same policies. Finally, regardless of the specific harms resulting from these issues, the unequal treatment of different populations based on their race is harmful in itself and constitutes racial discrimination.

\section{The West and the Other in the media: upholding racialised frames of genital modifications}

By examining how racial frames work in the media, in the second part of this article I discuss how the inconsistencies presented thus far in the paper are upheld in media representations. How is the comparison between different types of genital modifications avoided? I attempt to answer this question by engaging with two mainstream media outputs. First, to illustrate a case of cosmetic surgery, I will analyse Embarrassing Bodies, a British television show that claims to help the audience make autonomous decisions by providing them with knowledge. Later in the paper, I also analyse a representation of genital mutilation in an episode of the German series Tatort.

\section{Framing cosmetic genital surgery as realisation of autonomy}

The zero tolerance definition of genital mutilation by the UN does not consider questions of informed consent and autonomous decisions. However, the fundamentally different representations of what is usually considered as 'African' mutilation and 'Western' cosmetic surgery imply that Western women seeking surgery make autonomous choices unburdened by

\footnotetext{
${ }^{4}$ Female Genital Cutting, a term used by these authors to describe what is framed as African female genital mutilation.
} 
the cultural constraints with which their African counterparts have to live. In this section, I discuss how a television show frames cosmetic surgery and the decisions of the patients who seek those practices. How do promoters of cosmetic surgery put forward body ideals and suggest the need for it while, at the same time, protecting the image of cosmetic surgery consumers as autonomous individuals?

The British television show Embarrassing Bodies has been on air since 2007 (Maverick Television). The producers describe it as 'an innovative attempt to raise health awareness and de-stigmatise 'embarrassing' body parts and medical conditions' (Channel 4 n.d.). Therefore, it is well-suited to serve as an example for how cosmetic surgery is framed in these shows.

Allison, a single woman in her forties, enters the office of Dr McKenna, one of the consulting doctors (Series 2, episode 3). Allison feels burdened by her enlarged labia. The consultations, operations and reviews between the doctors and Allison provide plenty of examples of how body ideals are enforced while, at the same time, the autonomy of women seeking cosmetic surgery is protected rhetorically. The doctors legitimise themselves by performing the role of educators about anatomy. They highlight the fact that bodies come in different shapes, for example, when they discuss penis size or when they enlighten women about the variety of breast sizes. The doctors mix their aesthetic advice with actual medical counsel when they discuss medically relevant conditions such as fungal infections alongside cosmetic issues. It could also be argued that the explicit visuals of the surgeries add to the credibility of the show and serve as a pre-emptive defence against criticisms of sugar-coating the procedures. However, posing as educators about the varieties in shape of the human body does not preclude them from using terms such as 'embarrassing' and 'abnormality', just a few seconds after pointing out its normality.

Allison's labia are presented as a psychological problem with daily consequences in need of surgery. Allison points out that: 'the debilitating factor for me is psychological, it is mental, it is what I will and won't do in the intimacy of my bedroom. And this means I won't easily undress in front of somebody. I won't do certain acts in bed'. Her point is emphasised when the off-screen narrator affirms: 'Dr Cavuni suggests a surgical technique to take the weight off Allison's mind and remove her little secret'. The psychological burden constitutes the central theme of the five-minute broadcast analysed here, which affirms Allison's apprehension about her labia in various ways: Dr McKenna identifies 'quite a lot of excess skin' and that the lips stick out, apparently an appearance 'you normally wouldn't get'. Dr McKenna argues that some women look like Allison: 'Women will come in for a smear or whatever reason, and they will have a similar appearance as yourself. But for some women, it doesn't bother them'. Even when the doctors describe Allison's anatomy as normal, there is a backhanded affirmation of abnormality.

Dr McKenna requests: 'Don't think you are abnormal or you are a freak. What you have got is a normal variant'. This is immediately followed by a suggestion to perform Type IIa of female genital mutilation, or partial removal of the inner labia, referring to the practice as labiaplasty. Allison asks the surgeon whether she can make her look 'okay down there', and the surgeon promises to 'remove that excess skin'. Dr Cavuni elaborates: 'the problem is more on the right hand side, there is a degree of asymmetry', to which Allison replies: 'It is horrible, isn't it?'. Dr Cavuni: 'It is not horrible. But definitely, there is too much tissue there'. The measure against which the tissue is too much remains unclear, while the judgement is backed by the professional authority of both doctors. The narrator completes the normalisation of labia when, with a disparaging tone, she comments on a close-up shot of the 
cut-off labia on the operating table: 'when Allison comes around, she will be comfortable in the knowledge that she won't be going home with these'. This shot can be read in terms of the visual aesthetics of the broadcast, using explicit imagery to both attract viewers by shock value and creating a medical atmosphere for the broadcast. At the same time, it visually emphasises the notion of excessive flesh. Given that similar images are often used on television to depict diseased flesh, such as cancerous tissue, we could argue that the shot of the cut-off labia reinforces the suggestion that the labia did not properly belong to her body.

Furthermore, Allison is portrayed as having to struggle for her autonomy against the societal pressure not to go under the knife. She ponders about her decision and affirms her autonomy against expectations from others: 'Maybe it is neurotic, but it matters to me and that is all I care about, really'. The desire to go under the knife is sometimes represented as having to overcome the hesitations expressed by doctors, who struggle to understand the severity of the patients' problems. Cosmetic surgery is displayed as an inner need, which the plastic surgeon accepts, though somewhat reluctantly. This is also the case of a woman with an inverted nipple that has, in her account, hampered her whole life:

Dr McKenna: Have you ever shown it to a doctor or to anyone you have been close to?

Patient: No.

Dr McKenna: You are joking?

Patient: No.

Dr McKenna: So you never ever have shown this to anyone?

Patient: No. I feel like a complete freak.

Dr McKenna: Do you?

Dr McKenna then accepts the severity of the psychological impact: 'This isn't a life threatening problem. But clearly, it is a life-impacting problem and I think it would be worth you having a chat with a specialist' to consider an operation.

The person wishing to undergo a body modification has to express an inner need for this procedure by connecting it with their own insecurities, which come from inside, and not from the social surroundings. After the surgery, they have to prove how this external solution to an internal problem has freed them. After the healing process, the woman with the inverted nipple stated that 'I have shown them to my partner, but it was more for myself. I just wanted to feel normal'. When asked what she thought it would enable her to do, she claimed that she would 'maybe wear a bikini. That would be nice'. The same is true for Allison. After being freed from parts of her labia, she is looking forward to a complete change in her relationships: 'I suppose I am hoping that the next relationship that I have, all the insecurities will be completely gone'.

The women here are depicted as struggling. Their struggle is to do something about the embarrassing body they have. They not only have to overcome their own body, but also the social environment, which does not understand the intensity of their suffering. This representation manages to build pressure to undergo cosmetic surgery and protect its consumers' individualism and autonomy at the same time: (1) it reinforces a specific vision of a perfect body, (2) yet de-emphasises pressures resulting from social body ideals; (3) the desire for cosmetic surgery is depicted as an important inner need that just happens to overlap with social views of the perfect body; and (4) it portrays consumers of cosmetic surgery as overcoming social pressures against it and, thereby, as fighting for their authentic self- 
actualisation. In the process, labia, which are embodiments of human rights in one context, are reduced to excessive skin in another.

\section{A standard tale of African female genital mutilation in Tatort}

Tatort, which translates into 'crime scene', is a German-Austrian-Swiss public broadcast coproduction (ARD, ORF, SF) running since 1970. Broadcast at prime time on Sundays, the stand-alone ninety-minute episodes feature various investigator teams and are viewed by seven to twelve million Germans on average (excluding repetitions as well as Internet streaming), making them one of the most popular broadcasts in Germany. ${ }^{5}$

The cultural significance of the Tatort series is widely recognised. It has created iconic characters and has a close relationship with the German society (Hickethier 2010). It has the capacity to initiate, coin and enrich societal discourses and, at the same time, reacts to, and is shaped by, societal change (Gräf 2010, 9). The series is also known for deliberately engaging with social problems. The New York Times has described Tatort as a 'modest pop-culture symbol' and a 'long-standing common experience' of Germans that 'speaks to and of the nation' (Kimmelman 2009, 1).

German public broadcasters have been politically committed to the promotion of cultural diversity and societal integration. This includes, but is not limited to, the integration of migrant populations into German society. German public broadcasters understand this as a cross-sectional task, spanning production (a culturally more diverse work force), reception (reaching a more culturally diverse audience) and content (representation of cultural diversity in fictional as well as non-fictional shows). This includes the pledge not to present migrants primarily in problem-oriented contexts but, rather, to foster mutual understanding and an avowal against racism (Wolf 2011, 124-130).

Yet, a study by Paasch-Colberg and Küfner (2012) has revealed that the depiction of characters with migration backgrounds within Tatort is more complex. Roles that depict Germans with migration backgrounds have played the protagonist role more often recently, and their storylines have also become more complex over time. Evidence also suggests that the Tatort series may play with, and ultimately undermine, stereotypes about criminal migrants (Paasch-Colberg and Küfner 2012, 406-408). At the same time, however, the crime rate among characters with migration backgrounds is high. Since 2005, episodes focus more on migration or intercultural issues, when characters with migration backgrounds are involved in the plot (405). This could be interpreted in at least two ways: either as marginalising people by refocusing on their migration backgrounds, or as acknowledging the problems that Germans and non-Germans with migration backgrounds face within the German society.

Another crucial finding for this analysis is the fact that, from 2005 to 2009, forty percent of the characters with a migration background have been connected to either forced marriage or 'honour killings' when placed in a plot primarily concerned with migration, inter- and multicultural issues (Paasch-Colberg and Küfner 2012, 405). In German discourses on

\footnotetext{
${ }^{5}$ In 2011, Tatort episodes averaged a little over eight million viewers (a market share of 22.7\%) (Zubayr and Gerhard 2012,130). The list of the ten most viewed feature films of the same year consists entirely of Tatort episodes (Zubayr and Gerhard 2012, 130). Viewership happens in communal contexts: groups of friends meet up to watch it together, and bars display the series on Sunday evenings in most German towns (Gscheidle, Mohr and Niederauer-Kopf 2011, 202).
} 
multiculturalism, both practices connote the Other. It is against this backdrop that I use a Tatort episode as an example of how 'African genital mutilation' is framed in German media.

A woman is found dead in her living room, tied up and drowned in a water fountain. This is the beginning of 'Death of a teacher', the $809^{\text {th }}$ instalment of Tatort. ${ }^{6}$ The investigators, a middle-aged female lead with her male sidekick (both of whom have no migrant background), follow up on various leads during the episode. Dramaturgically, however, it is evident that a Somali family will play a special role as the plot develops. Eshe, a sixteenyear-old pupil of the victim, had fled Somalia three years earlier together with her little sister Mesa and her mother Dafina. Dafina is widowed and has married a German man to be allowed to stay in Germany. Dafina is employed as an assistant by a German doctor who had worked many years in Somalia.

Racism is addressed within the first five minutes of the episode. A neighbour of the deceased, who is introduced negatively as not caring for his neighbours and being rude, makes a racist remark about Eshe when he was asked whether she lived in his house. The detective dismisses him. At other times, characters mention Eshe's excellent grade in her German class, a politically charged symbol of integration in German society. Her mother, Dafina, insists on the fact that she is not receiving social benefits, even though the investigator neither insinuated that she was, nor that it would be seen as negative if this was the case. This scene implies that Dafina experiences social pressure and is perceived as a 'scrounger' by some, but not by the detectives, who serve as a moral compass throughout the plot. This stance reflects the political, social and cultural context of the Tatort series in particular, and German public broadcasting in general, setting the episode up to address female genital mutilation as a cultural problem without being perceived as racist.

I argue that 'Death of a teacher' is not racist in an overt or deliberate way, but it does rely on a racialised understanding of genital mutilation. This understanding is expressed in several ways, of which I will discuss three aspects: the representation of tradition, the justifications given by culprits, and the depiction of female genital mutilation.

During this episode, Dafina and the doctor maintain a conversation (minute seventeen), where Dafina seems to extort secrecy from him about an unknown issue. This is highlighted by a slow stare by Dafina, which she repeats later in the episode, setting her up as secretive. One minute later, her husband explains that he had to come along to Eshe's class trip because her mother thought that girls her age are not supposed to travel on their own. He explains that Dafina is 'strict and traditional that way'. This is emphasised when Eshe blocks advances by a classmate on her way home from school. She puts on a headscarf (even though her mother does not wear one) and turns the corner, only to see her mother staring at her from the window with a stern expression. This further represents Dafina as traditional and controlling. Later on, it emerges that Dafina plans to mutilate her youngest daughter Mesa and that Eshe is determined to stop her. In an abandoned housing complex, Dafina meets with a dozen of other black women, whose descent or nationality is not revealed, to execute the practice. They are clothed in the same garment and sing, with several young children in the middle. This is clearly a cultural setting, rather than a medical one. When Eshe tries to stop her mother, Dafina evokes honour and accuses Eshe of being a disgrace to her people.

\footnotetext{
${ }^{6}$ During its premiere on 11 September 2011, 'Death of a teacher' had a viewership of 7.9 million, equalling a German market share of 23.1 percent (Quotenmeter GmbH 2011).
} 
While the traditional element is quite explicit, the juxtaposition of tradition to rationality is more subtle. During the episode, we learn that Dafina is a doctor's assistant, and lives in Germany. Therefore, she presumably experiences less pressure to conform to the norm of mutilation than she would if she lived in Somalia. More importantly, we also learn that she has been a circumciser back in Somalia and one of her daughters had already died after Dafina had mutilated her. The combination of these three aspects -medical background, new social surroundings, and a horrific personal experience- leads to questions about her motive to continue performing this practice.

A motive-elucidating monologue of the culprit is a prominent feature of Tatort. One of the series' known tenets is not to Other the culprit into a demonic being. Notably, characters that provoke this type of representation, such as serial killers, are very rare in Tatort. A similar observation is made in relation to the concept of evil, as many episodes deliberately blur the distinction between the law-abiding and the law-breaking, and tend to emphasise the banality of crime and the criminal. This point is made by Brück and Viehoff (1998), who argue that in Tatort

it often seems undecidable who the real criminal actually is and who should be punished. Anyway, it is true in Tatort, that the legally punished criminals [...] are not the ones who should be punished from a moral point of view (10).

Tatort instalments are regularly based on moral dilemmas, often showcasing culprits who have been traumatised or affected by previous events. In 'Death of a teacher', there are three culprits: the doctor, who had performed genital mutilations to reduce the risk of resulting complications during his time in Somalia and in Germany due to Dafina's extorsion; his wife, who discovered her husband's actions and killed the teacher, who had threatened to expose him; and Dafina, who was a circumciser in Somalia, extorted the doctor and planned the mutilation of her own daughter Mesa.

However, a motive-elucidating monologue is granted to the doctor and to his wife, but not to Dafina. The doctor's arguments for harm reduction receive some space and recognition, even though the investigators do not accept them. His wife, the murderer, describes in her monologue how she did not quite murder her, but just did not intervene when the victim (drugged and tied up by someone else) slipped into the water fountain. As in other Tatort episodes, the motive-elucidating monologue is granted to perpetrators of severe crimes.

Dafina's actions would also require some explanation, since she seeks to mutilate her daughter even though she had already lost another child in similar circumstances. Yet, Dafina has no opportunity to offer such monologue. It is up to the doctor to provide a brief, general explanation about these practices in some parts of Africa, and he does so by referring to the traditional element:

It is a millennia old tradition. Only a circumcised girl is seen as beautiful and pure. Only then she can be married, because it has been sewn shut. Thus, the man can be sure to marry a virgin. No religion demands this. No Qur'an, no Bible and no law. And, nevertheless, it is done.

This speech does not explain, however, why a mother that has lost her daughter due to having mutilated here, and who has integrated into a society that is horrified by this act, would still seek to mutilate another daughter. 
Dafina's denied opportunity to explain the rationale behind her actions can be understood as banishment from the circle of law breakers whose actions are explained as partly comprehensible. This is further highlighted in a dialogue between the detectives after they dismantled the mutilation circle:

Investigator 1: To be insulted as colonial police is a first.

Investigator 2: They think they are in the right.

Investigator 1: Two cultures don't understand each other, and it has nothing to do with language.

Investigator 2: For me, this is the point where tolerance stops!

While, in fact, all crimes in Tatort cannot be tolerated, in 'Death of a teacher' female genital mutilation is still framed as an 'unspeakable atrocity', as Daly (1981) once wrote attracting the criticism of postcolonial scholars. Female genital mutilation is the symbol of the Other in its purest form, as it is completely alien.

The episode, however, is careful not to qualify the Other as racial, but as cultural. Juxtaposing Dafina's stubborn traditionalist view with her teenage daughter's attempt to protect her little sister from mutilation serves to avoid the impression that 'Death of a teacher' portrays a racially defined Other. Dafina's actions are not determined by her Africanness or blackness. Eshe's resistance proves the cultural nature of Dafina's position, as well as the fact that Eshe has the possibility of escaping 'her culture'. Yet, at the same time, the creation of the cultural Other is still thoroughly racialised, due to the ways in which subjects are culturalised in the first place.

Even though the Other is construed as alien, there is no attempt to engage with this Otherness because, paradoxically, the explanation is already at hand: as Dafina's husband points out several times throughout the episode, tradition is what causes Dafina to act the way she does, which is something that Westerners supposedly cannot connect to. 'Death of a teacher' therefore embodies what Leonard (2000) coined as the standard tale of female genital mutilation, by which practitioners cannot be comprehended, but can be explained as traditional (167).

'Death of a teacher' can be subjected to other criticisms as well, for example regarding the depiction of the practice. While the most common variants of what is framed as female genital mutilation are highly terrifying, there is still a tendency to represent the practice even more negatively. The depiction of 'barbaric' instruments plays a role in this construction. In the 1990s, UN organisations used the motif 'A kitchen knife, a razor-blade, a piece of glass, or even a sharp fingernail, are the tools of the trade' (OHCHR 1995, 4). Some authors have claimed that some circumcisers would bite off the clitoris of girls (Barstow 1999, 503; Joseph 1996). However, among the hundreds of studies analysed for this research, I have not come across one single record of a random piece of glass, fingernail or teeth being used to mutilate African girls. For instance, Gausset (2001) points out that 'in Zambia, razor blades are available everywhere, and everybody can afford them' (513).

According to my interviews with Tanzanian circumcisers, it is clear that they value clean and sharp instruments, and that most of them are concerned with blood-borne pathogens. Circumcisers and parents are, in most cases, compassionate with their daughters, but conceive the procedure as necessary. Furthermore, an increasing number of girls undergo the procedure in hospitals and by doctors: $46 \%$ of all girls in Kenya, $65 \%$ in Mauretania, $76 \%$ in 
Yemen and 94\% in Egypt (UNFPA et al. 2010, 3). In fact, UN organisations recognise this trend of medicalisation as one of the main problems in the struggle to end these practices in Africa. Yet, there is no imagery available for this development. Rusty, improvised knives are still central in the visualisation of the practice. It is this background that makes the depiction of Dafina's instruments significant, especially because she works in a medical setting. Her unpacking leather-bound, rusty, self-made knives has more to do with a cultural imagery than with anything else (even though Dafina finally applies some of her work expertise and sprays the knives with disinfectants). The widespread imagery serves to Other African practitioners and to make mutilation practices incomparable to what is framed as cosmetic surgery.

Moreover, the various meanings of the practice in different African communities remain unclear. Characters often speak about Africa as if it were one traditional and uncivilised place (Korieh 2005, 117). It is not mentioned that the practice is performed in twenty-eight nations, but it is certainly not present in all African countries. The existence of different forms of the practice is also omitted, suggesting that only infibulations, the worst variation, exist (AjayiSoyinka 2005, 62). That is not to argue that a fictional production necessarily has an obligation to provide such distinctions. From a positive perspective, the episode represents the fact that many people, both Germans and Afro-Germans or migrants from Africa, tend to homogenise Africa in intercultural communication. However, within the Tatort series, this lack of differentiation is conspicuous, as its mission to be socially relevant regularly results in explanatory dialogue, in which the audience is exposed to an issue through one character explaining it to others. For example, there are several scenes in the episode 'Scalpel', which revolves around gender assignment surgery, in which a detective explains the concept of intersexuality, how children are operated on, and how to judge this morally. Against this backdrop, Dafina's missing motive-elucidating monologue indicates that 'Death of a teacher' corresponds with the standard tale of female genital mutilation.

\section{Conclusions}

In this article, I have argued that a race-based self-image of the West determines an inconsistent approach to body modifications, and that this has led to negative consequences for various social groups. Rights are infringed, and bodies are not sufficiently protected. Overall, this race-based self-image obfuscates how, and on what principles, body modifications should be dealt with as a political and societal challenge. I have discussed how discourses on African female genital mutilation present African women as blinded by culture and tradition, while Western women are framed as autonomous and self-effacing (Hrzán 2005, 67-68; Obiora 1997, 315). I argue that, while there are several ways of approaching the representation of female genital mutilation, we should be consistent in the principles to classify these practices. Similar standards are not considered in current political and media discourse. The differences in practices and circumstances may merit different approaches to the body modifications discussed here. For example, the intensity of the social pressure, is in nearly all cases of what is usually called 'African' female genital mutilation higher than in the other practices mentioned here. Regardless, classifications should not be race-based. For example, one has to decide on the issue of body modification on minors who are unable to consent to procedures. The severity and irreversibility of the practices should be considered in these cases, but the decision should not depend on whether the reasons for the procedure seem alien or familiar to 'us'.

The media rely on highly standardised imagery and exclude phenomena, such as minimally invasive procedures, which do not fit the racial framing of the established narratives. Media 
misrepresentations are construed through omission and through the repetition of established narratives based on the use of predictable stereotypes. Western rationality, modernity, individualism and autonomous decision-making contrast with the cultural and traditional African Other, leading to oversimplification and ignorance of the actual similarities between the practices and people involved. The double standards regarding the practices in international politics demonstrate the power of racialised framings of body modifications.

\section{References}

Ajayi-Soyinka, O. (2005) 'Transcending the Boundaries of Power and Imperialism: Writing Gender, Constructing Knowledge', in O. Nnaemeka (ed.) Female circumcision and the politics of knowledge. African women in imperialist discourses, Westport: Praeger (pp. 47-77).

Barstow, D.G. (1999) 'Female Genital Mutilation: the penultimate gender abuse', Child Abuse \& Neglect, 23, 5, 501-510.

Benatar, M. and Benatar, D. (2003) 'Between prophylaxis and child abuse: the ethics of neonatal male circumcision', American Journal of Bioethics, 3, 2, 35-48.

Boulware-Miller, K. (1985) 'Female Circumcision: Challenges to the Practice as a Human Rights Violation', Harvard Women's Law Journal, 8, 155-177.

Brück, I. and Viehoff, R. (1998) 'Stahlnetz, Tatort, Polizeiruf 110: Transitions in German Police Series', in R. Viehoff (ed.) Stahlnetz, Tatort, Polizeiruf 110: Transitions in German Police Series, HALMA: Hallische Medienarbeiten 8 (pp. 3-11).

Channel 4 (n.d.) Embarrassing Bodies. Available from: http://www.channel4.com/programmes/embarrassing-bodies [accessed 9.9.2014].

Coleman, D. L. (1998) 'The Seattle Compromise: Multicultural Sensitivity and Americanization', Duke Law Journal, 47, 4, 717-783.

Daly, M. (1981) Gyn/Ökologie: Eine Meta-Ethik des radikalen Feminismus, München: Verlag Frauenoffensive.

Danelzik, M. (forthcoming) Kulturen verändern. Kampagnen gegen weibliche Genitalverstümmelung zwischen ethischen Idealen und strategischen Herausforderungen, Wiesbaden: VS Verlag.

Ehrenreich, N. and Barr, M. (2005) 'Intersex Surgery, Female Genital Cutting, and the Selective Condemnation of "Cultural Practices"', Harvard Civil Rights-Civil Liberties Law Review, 40, 1, 71-140.

Equality Now (2010) Letter from Equality Now to the American Academy of Pediatrics regarding its policy on FGM. Available from: http://www.equalitynow.org/node/584 [accessed 9.9.2014]. 
Essén, B. and Johnsdotter, S. (2004) 'Female genital mutilation in the West: traditional circumcision versus genital cosmetic surgery', Acta Obstetricia et Gynecologica Scandinavica, 83, 7, 611-613.

Fausto-Sterling, A. (2000) Sexing the Body. Gender Politics and the Construction of Sexuality, New York: Basic Books.

Galeotti, A.E. (2007) 'Relativism, Universalism, and Applied Ethics: The Case of Female Circumcision', Constellations, 14, 1, 91-111.

Gausset, Q. (2001) 'AIDS and cultural practices in Africa: the case of the Tonga (Zambia)', Social Science \& Medicine, 52, 4, 509-518.

Gosselin, C. (2000) 'Feminism, Anthropology and the Politics of Excision in Mali: Global and Local Debates in a Postcolonial World', Anthropologica, 42, 1, 43-60.

Gräf, D. (2010) Tatort: Ein populäres Medium als kultureller Speicher, Marburg: Schüren.

Gray, R.H., Kigozi, G., Serwadda, D., Makumbi, F., Watya, S. and Nalugoda, F. (2007) 'Male circumcision for HIV prevention in men in Rakai, Uganda: a randomised trial', Lancet, 369, 8, 657-666.

Green, F.J. (2005) 'From clitoridectomies to "designer vaginas": The medical construction of heteronormative female bodies and sexuality through female genital cutting', Sexualities, Evolution and Gender, 7, 2, 153-187.

Gruenbaum, E. (1982) 'The Movement Against Clitoridectomy and Infibulation in Sudan: Public Health Policy and the Women's Movement', Medical Anthropology Newsletter, 13, 2, 4-12.

Gscheidle, C., Mohr, I. and Niederauer-Kopf, K. (2011) 'Fernsehnutzung "außer Haus". Ergebnisse aus dem AGF/GfK-Fernsehpanel zur Gästenutzung', Media Perspektiven, 15, 4, 195-203.

Hickethier, K. (2010) "Tatort" und "Lindenstraße" als Spiegel der Gesellschaft', Aus Politik und Zeitgeschichte, 60, 20, 41-46.

Hrzán, D. (2005) 'Sind alternative "Erzählungen” über Female Genital Cutting (FGC) möglich? Erste Schritte auf dem Weg zu kritischen Weißen feministischen Perspektiven', in Zentrum für transdisziplinäre Geschlechterstudien der HumboldtUniversität zu Berlin (ed.) Female Genital Cutting: Die Schwierigkeit, sich zu positionieren. Berlin (pp. 57-69). Available from: https://www.gender.huberlin.de/publikationen/gender-bulletins/texte-28/bulletin-texte-28 [accessed 9.9.2014]

Jeffreys, S. (2005) Beauty and Misogyny: Harmful Cultural Practices in the West, London: Routledge. 
Joseph, C. (1996) 'Compassionate Accountability: An Embodied Consideration of Female Genital Mutilation', Journal of Psychohistory, 24, 1, 2-17.

Kasten, E. (2006) Body-Modification: Psychologische und medizinische Aspekte von Piercing, Tattoo, Selbstverletzung und anderen Körperveränderungen, München: Ernst Reinhard Verlag.

Kessler, S.J. (1998) Lessons from the Intersexed, Piscataway: Rutgers University Press.

Kimmelman, M. (2009) 'German Viewers Love Their Detectives', New York Times, 27 August, 1.

Kohl, K.H. (2006) 'Coming Back to one's own: What happens to tradition in neotraditionalist movements?', in R. Rottenburg, B. Schnepel and S. Shimada (eds.) The making and unmaking of differences. Anthropological, sociological and philosophical perspectives, Bielefeld: Transcript (pp. 97-105).

Korieh, C. (2005) 'Other" Bodies: Western Feminism, Race, and Representation in Female Circumcision Discourse', in O. Nnaemeka (ed.) Female circumcision and the politics of knowledge. African women in imperialist discourses, Westport: Praeger (pp. 111-132).

Leonard, L. (2000). "We Did It for Pleasure Only": Hearing Alternative Tales of Female Circumcision', Qualitative Inquiry, 6, 2, 212-228.

Mackie, G. (n.d.). Ending Harmful Conventions: Liberal Responses to Female Genital Cutting. Available from: http://dss.ucsd.edu/ gmackie/documents/LiberalResponsesFGC.pdf $\quad$ [accessed 9.9.2014].

Nnaemeka, O. (ed.) (2005) Female circumcision and the politics of knowledge: African women in imperialist discourses, Westport: Praeger.

Obiora, L.A. (1997) 'Bridges and Barricades: Rethinking Polemics and Intransigence in the Campaign against Female Circumcision', Case Western Reserve Law Review, $47,2,275-378$.

OHCHR (1995) Fact Sheet No. 23, Harmful Traditional Practices Affecting the Health of Women and Children. Genf. Available from: http://www.unhcr.org/refworld/docid/479477410.html [accessed 9.9.2014].

Paasch-Colberg, S. and Küfner, A. (2012) 'Zur Repräsentationsleistung von FernsehFiktion. Die Darstellung von Migranten im Tatort der Jahre 1970 bis 2009', Medien \& Kommunikationswissenschaft, 60, 3, 392-413.

Pedwell, C. (2007) 'Theorizing "African" female genital cutting and "Western" body modifications: a critique of the continuum and analogue approaches', Feminist Review, 29, 2, 45-66. 
Pedwell, C. (2012) Feminism, culture and embodied practice: The rhetorics of comparison, London: Routledge.

Quotenmeter GmbH (2011) 'Primetime-Check: Sonntag, 11. September 2011'. Available from: http://www.quotenmeter.de/cms/?p1=n\&p2=51960\&p3 [accessed 9.9.2014]

Reiter, B.M. (1999) 'Genitale Korrekturen an intersexuellen Menschen', in F. DiabyPentzlin and E. Göttke (eds.) Einschnitte. Materialband zu Female Genital Cutting (FGC). Eschborn: GTZ (pp. 95-100).

Rennie, S., Muula, A.S. and Westreich, D. (2007) 'Male circumcision and HIV prevention: ethical, medical and public health tradeoffs in low-income countries', Journal of Medical Ethics, 33, 6, 357-361.

Schultheiss, C.E. (2010) 'The Ethics of Non-Therapeutic Neonatal Male Circumcision', Penn Bioethics Journal, 6, 2, 21-24.

Sheldon, S. and Wilkinson, S. (1998) 'Female Genital Mutilation and Cosmetic Surgery: Regulating non-therapeutic body modifications', Bioethics, 12, 4, 263-285.

Shell-Duncan, B. (2001) 'The medicalization of female "circumcision": harm reduction or promotion of a dangerous practice?', Social Science \& Medicine, 52, 7, 10131028.

Shell-Duncan, B. (2008) 'From Health to Human Rights: Female Genital Cutting and the Politics of Intervention', American Anthropologist, 110, 2, 225-236.

Shell-Duncan, B. and Hernlund, Y. (2000) 'Female "Circumcision" in Africa: Dimensions of the Practices and the Debate', in B. Shell-Duncan and Y. Hernlund (eds.) Female "Circumcision" in Africa. Culture, Controversy, and Change, Boulder: Lynne Rienner Publishers (pp. 1-40).

Sullivan, N. (2007) "The Price to Pay for our Common Good": Genital Modification and the Somatechnologies of Cultural (In)Difference', Social Semiotics, 17, 3, 395409.

UNAIDS (2010) Neonatal and child male circumcision: a global review, Geneva: UNAIDS.

UNFPA, UNHCR, UNICEF, UNIFEM, WHO and FIGO (2010) Global strategy to stop health-care providers from performing female genital mutilation, Geneva: WHO Press.

UNFPA and UNICEF (2008) UNFPA-UNICEF Joint Programme: Female Genital Mutilation/Cutting: Accelerating Change: Annual Report. Available from: http://www.unfpa.org/public/publications/pid/2944 [accessed 10.10.2012]. 
UNHCR (1995) Harmful Traditional Practices Affecting the Health of Women and Children: Fact Sheet. Available from: http://www.unhcr.org/refworld/docid/479477410.html [accessed 9.9.2014].

WHO, UNFPA, UNICEF and UNIFEM (2010) Regarding the "Policy Statement Ritual Genital Cutting of Female Minors" from the American Academy of Pediatrics. Available from: http://www.who.int/reproductivehealth/topics/fgm/fgm app statement.pdf [accessed 9.9.2014].

Wolf, F. (2011) Interkulturelle Integration als Aufgabe des öffentlich-rechtlichen Fernsehens: Die Einwanderungsländer Deutschland und Großbritannien im Vergleich, Wiesbaden: VS Verlag.

Zubayr, C. and Gerhard, H. (2012) 'Tendenzen im Zuschauerverhalten. Fernsehgewohnheiten und Fernsehreichweiten im Jahr 2011', Media Perspektiven, $16,3,118-132$.

\section{Biography}

Mathis Danelzik is part of the research team of the project "Demoenergy", inquiring how to improve citizen participation in infrastructural planning, at the Institute for Advanced Study in the Humanities in Essen, Germany. His research interests include strategic communication and its ethics, communication for social/cultural change, deliberation and participatory communication. He received his Ph.D. from the Justus-Liebig-University Gießen, Germany, for his thesis on strategies and ethics of anti-female genital mutilation communication campaigns, especially regarding culturally sensitive approaches. He can be contacted at Mathis.Danelzik@kwi-nrw.de. 